\title{
Determination of disproportionate tenders in public procurement
}

\author{
Fuentes-Bargues J. L. ${ }^{1,2, *}$, González-Gaya C. ${ }^{3}$ \\ ${ }^{1}$ Dept. Proyectos de Ingeniería, Universidad Politécnica de Valencia, Valencia, Spain \\ ${ }^{2}$ Dept. Ingeniería Química, Universidad de Valencia, Valencia, Spain \\ ${ }^{3}$ Dept. Ingeniería de Construcción y Fabricación, UNED, Madrid, Spain
}

\section{Email address:}

jofuebar@dpi.upv.es (F. -B. J. L. ), cgonzalez@ind.uned.es (G. -G. C.)

\section{To cite this article:}

Fuentes-Bargues J. L. , González-Gaya C. . Determination of Disproportionate Tenders in Public Procurement. Journal of Investment and Management. Vol. 2, No. 1, 2013, pp. 1-9. doi: 10.11648/j.jim.20130201.11

\begin{abstract}
Public procurement is one of the fundamental pillars of the construction sector and the understanding of its statutory regulation is one of the keys to success. The government regulates the concept of disproportionate tenders to avoid deals that are too low, something which could jeopardise the execution of the work or cause problems during implementation such as conflicting prices, project modifications and delays. The criteria for determining the disproportionality of the offers are numerous and each contracting authority determines which to use in each process by carrying out a comparative analysis. The results show that the formulas of disproportionality based on a percentage of the bid price are not useful, and the convenience of formulas based on the determination of a low reference which is calculated from both the average of the offers and the standard deviation.
\end{abstract}

Keywords: Contract Management, Contractor selection, Construction Management, Tendering, Spain

\section{Introduction}

Public procurement is regulated in Europe by the European Directive 2004/18/EC [1], transposed into Spanish law by Law 30/2007, Public Sector Contracts (LPSC) [2], collecting the various changes in the Royal Decree 3/2011, by the approving the Revised Text of the Law on Public Sector Contracts (RTLPSC) [3].

Public procurement is based on principles of transparency, equality and the public attendance of any natural or legal person who fulfils the conditions for participation in a particular contract file.

The award of a contract by an administration depends on a number of endpoints that have been previously determined and published in the contract documents in the file. These criteria cover issues directly related to the subject of the contract, i.e. defining or identifying a project subject to tender, and should not be confused with the eligibility criteria of the bidders [4-5].

The criteria for awarding offers is determined by the price, quality, technical merit, aesthetic and functional characteristics, environmental characteristics, running costs, profitability, customer service, technical assistance, delivery date, the execution time, etc.., ultimately those allowing the contracting authority to select the most economically advantageous tender.

The optimum bid based on several criteria for the award is traditionally called the procedure contest, while the bid which is based solely on a single criterion, which, inexcusably, must be the price, is the procedure that has been traditionally called auction. The choice of endpoints and their scoring formulas or ranges are determined by the contracting authority, and published in the relevant contractual documents. These must be in keeping with the objective of the project tendered and obviously suited to the technical capabilities of winning party.

The contracting authority shall determine, in accordance with the criteria and previously established formulas for point scoring, the most economically advantageous tender, only after an analysis as to whether an offer presents abnormal or disproportionate values has been carried out. Article 152 of the RTLPSC determines the points to consider as to whether an offer or proposal is disproportionate or abnormal, which was previously considered by the LPSC as low risk.

As reference [6] highlighted, the concept of low risk is difficult to understand outside the field of public procurement, due to the fact within the private sector any contract- 
ing company will consider issues of low bidding lie with the bidders themselves, however the administration considers a different issue; the need to regulate lower bids in order to avoid problems later on in the execution of the contract. These issues could be conflicting prices, delays in implementation, etc. As indicated in [7] the appearance of low risk started to become more regulated as a kind of defence mechanism in the interest of the administration against contractors there by allowing the automatic exclusion of candidates and even the possible cancellation of bidding.

As noted in [8], and included in subsequent regulations, in [3] in Article 152.3, regardless of the procurement procedure, whether implementing a single criterion or several criteria, when the Procurement Bureau considers that an offer can be considered as disproportionate or abnormal, the bidder must provide an appropriate justification of the offer, based on the technical, organisational and economic terms to ensure a proper execution of the contract. This possibility can generate rules based on business policies and as such incur much lower bids compared to other competitors, even if that means disregarding the profit margin [9]. This is done in order to recuperate any reduction in profit in the knowledge that any changes or claims can bring about compensations that far outweigh the initial loss [10-11]. From this strategy one could coin phrases such as "bid your claims" [12] or "grab the contract and run" [13].

This has developed studies and research in behaviour models for contractors in order to identify opportunities in tenders highlighting the lowest most adequate bids through measuring the potential success of subsequent claims throughout the life of the contract [14]. In addition to this, the use of neural networks in order to extract knowledge by way of appropriately selecting contractors [15], low-bid prediction models [16-17] or in multi-selection methods for the determination of criteria (and their importance) in the selection of contractors [18-20].

Determining low risk within the Spanish legislation prior to the LPSC was carried out through an objective formula; mandatory for contracts with a sole award criterion: the lowest price, i.e. an auction.

As stated in the State Procurement Regulations [21], Article 109, when an auction was to be carried out, an offer would be regarded as disproportionate or reckless when there was a percentage excess of at least 10 points. This was cross referenced with the average of the lowest rates of all proposals submitted. However, the Regulation of the Law on Public Administration Contracts (LPAC) [22], Article 85, when an auction was to be carried out, an offer would be considered disproportionate or reckless according to the following conditions:

" 1 . When, with a single bidder, the bid is lower than the base budget by more than 25 percentage points.

2. When, with two bidders, whichever bid is lower by more than 20 percentage points in comparison to the other offer.

3. When, with three bidders, any bid is lower by more than 10 percentage points to the average of the bids submitted.
However, bids which exceed the average by 10 percentage points will also be excluded. In any case, any bid will be considered disproportionate with a difference of 25 percentage points.

4. When, with four or more bidders, any bid lower by more than 10 percentage points to the arithmetic average of the bids submitted. However, if among those deals, any were above that average by more than 10 percentage points, a new average will be calculated to take into account the new offers not indicated by the aforementioned circumstances.

In any case, if the number of remaining bids is less than three, the new average will be calculated on the three lowest bids".

In the LPSC and the TRLPSC no objective formulas nor obligatory bidding upon various contracts appear, although during the processing of the Law 30/2007, the Popular Parliamentary Party proposed both in the Congress of Deputies and the Senate the amendments (number 84 and 18 respectively) to add a second paragraph to Article 136.2 delimiting even further the consideration of disproportionality or abnormality, which stated: "In any case, a tender will be considered disproportionately low when its base rate is more than five percentage points above the average or alternatively when the base rates exceed the average calculated from the standard deviation. Thus to calculate the mean baseline all bids submitted are considered and those that offer plus or minus $10 \%$ from the average of all bids submitted are removed". However, that was not included in the final texts or in the subsequent regulatory developments.

Previous legislation could not make extensive assumptions around auction temerity without further information (Report 18/96 of the Advisory Board on State Administrative Contracting, ABSAC) [23] due to the inhomogeneous nature of competitions and the fact that it is difficult to understand those case in which even a bidder with the highest score (both technical and economic) would not be awarded a contract for having offered too low a price [6]. LPAC incorporating provisions of [23], Article 86.3 states that "the contracts to be awarded by competition may contain specific objective criteria which state, where applicable, that the proposition cannot be fulfilled because of disproportionate or reckless tenders". The Report 27/98 of the ABSAC [24] states that: "unlike an auction, a competition must admit various forms of price evaluation, assuming that that approach is used, provided there is no contradiction to the requirements of EU Directives and Public Administration Contract Law specifically of not being permitted to automatically reject abnormally low proposals without previous verification and testing for viability."

The reports of the ABSAC and the European Commission Opinion of 23rd December, 1997 and subsequent reports of the regional advisory boards are to include amendments to the Procurement Act [8], which are as follows:

As stipulated in contracts awarded through competitions, objective criteria will be taken into account, where applicable, to judge whether a proposition cannot be accepted due to disproportionate or reckless tenders. 
The automatic exclusion of tenders alleged to be reckless or disproportionate will be forbidden. It will be the responsibility of the contracting authority to request the appropriate justifications surrounding the bidder's offer.

The Report 28/05 of the ABSAC [25] which states that "if particular contract clauses contain no mention of disproportionate or reckless deals and formulas to identify them, then they are not viable for consideration in the bidding process". Furthermore, under the LPSC, the report 58/08 of the ABSAC [26], reiterates ".... understanding whether a proposition cannot be fulfilled on the grounds that it is an abnormally low tender, as covered by the public administrations law and the Public Sector Contracts law, when a bid is to be awarded by a competition, the must be various evaluation criteria in place to measure the viability of all tenders". In other words, a regulatory framework for evaluating disproportionate offers must be established.

It seems clear from the evolution of national regulations that from interpretations of the ABSAC and European Directives, that for the evaluation of disproportionate or abnormal tenders, initial objective formulas within the procurement specifications must be established and secondly, the parameters must be laid out to provide adequate normative regulation $[7,27,28]$. This, so far, has not occurred.

With this regulatory framework it is useful to analyse exactly what is happening in practice, i.e. what formulas or criteria are being applied by different contracting authorities and to monitor their reactions under the current legal parameters.

\section{Methodology}

The study methodology for the analysis of formulas or criteria of the disproportionality of bids begins with data collection from the Works Projects, with their respective administrative clauses. A selection of one hundred samples of these Works Projects was set out, all of which tendered by the public sector reflecting different characteristics of the sector: Civil Works and Building subsectors, local, provincial, regional and national levels, several criteria upon which price played an important part, distribution throughout the country, etc. The data to be obtained for the study were the administrative terms and techniques, the invitation to tender and project execution, not least the budget and justification of indirect costs.

In the sample of collected bids, twenty-six different formulas were determined to highlight the disproportionality of tenders. In sixteen cases there were no references made in the administrative clauses as to the disproportionality criteria surrounding the bids. These formulas or scoring criteria, depending on their characteristics have been organised into eight groups.

Group A. Disproportionality criterion based on a Reference Base Rate plus a differential, previously having eliminated from the calculation the base rate of those tenders deviate from the high to low mean deviation of all classic offers or base rates.
The calculation of the Base Rate is made with the formula (1) with the base rates which apply to the condition (2):

$$
\begin{gathered}
B R=\frac{\sum_{h=1}^{n^{\prime}} B O_{h}}{n^{\prime}} \\
\mid B O_{j}-B M \leq \sigma
\end{gathered}
$$

Where the standard deviation and the mean of the bids is calculated according to:

$$
\begin{gathered}
\sigma=\left[\frac{\sum_{j=1}^{n}\left(B O_{j}\right)^{2}-n \cdot(B M)^{2}}{n}\right]^{1 / 2} \\
B M=\frac{\sum_{j=1}^{n} B O_{j}}{n}
\end{gathered}
$$

In this group, up to five possible variants of the criterion are determined and are shown in the following table:

Table 1. Variations of disproportionality criterion based on a Base Rate plus a differential.

\begin{tabular}{ll}
\hline A1 & Base Rate plus 4.5 percentage points \\
\hline A2 & Base Rate multiplied by a coefficient of 1.2 \\
A3 & Price Rate multiplied by a coefficient of 0.95 \\
A4 & Base Rate plus 4 percentage points \\
A5 & Price Rate multiplied by a coefficient of 0.94 \\
\hline
\end{tabular}

Group B. Those who apply the provisions of article 85 of the Regulation of the Law on Public Administration Contracts, either by referring directly to the articles or literally copying the assumptions described in that article.

Group C. Without disproportionality criteria defined in the specification. The majority of the auctions from the study sample fall into this category.

Group D. Disproportionality criteria are based on the assumptions of Article 85 of the Rules of the Contracts of Public Administrations, but the percentages or regulatory differentials vary. Among which two specific criteria are mentioned. They have been called D1 and D2 in the analysis. The D1 determines a differential of 5\% and D2 determines a differential of $7 \%$, these are more restrictive than the $10 \%$ specified in article 85 of the Regulations of the LPAC.

Group E. Those cases in which any disproportionality is determined when the lowest offers are higher than the average lowest bid plus a differential. In this case eight were 
analysed to test variations according to the following table:

Table 2. Variations of disproportionality criterion based on Mean Base Rate tenders plus a differential.

\begin{tabular}{ll}
\hline E1 & Mean Base Rate plus a differential of 5 percentage points \\
\hline E2 & Mean Base Rate plus a differential of 10 percentage points \\
E3 & Mean Base Rate plus a differential of 7 percentage points \\
E4 & Base Rate multiplied by a coefficient of 0.75 \\
E5 & Mean Base Rate plus a differential of $10 \%$ \\
E6 & Mean Base Rate plus a differential of 15 percentage points \\
E7 & Mean Base Rate plus a differential of 20 percentage points \\
E8 & Mean Base Rate plus the standard deviation of the tenders \\
\hline
\end{tabular}

Group F. Criteria where disproportionality occurs when bids are lower than the average of the tenders submitted plus a differential, in this case there are four variations of the criteria shown in the following table:

Table 3. Variations of disproportionality criterion based on the average of the tenders plus a differential.

\begin{tabular}{ll}
\hline F1 & Average of tenders minus 5\% \\
\hline F2 & Average of tenders minus $10 \%$ \\
F3 & Average of tenders minus $20 \%$ \\
F4 & Average of tenders minus the standard deviation \\
\hline
\end{tabular}

Group G. The disproportionality is determined by a percentage of the bid price. We have identified five versions, those in keeping with base rates or offers which account for $10,12,15,20$ and $25 \%$ of the bid price. (G1, G2, G3, G4, G5).

Group H. In this group disproportionality criteria are contemplated across cases which do not correspond to any of the aforementioned groups. In these cases a criterion sets out a Maximum Base Rate of $18.56 \%$ which corresponds to more than ten percentage points.

Fig. 1 shows the distribution of disproportionality criteria for certain groups. The criteria being used, first Group E with $24 \%$, i.e. those in which the disproportionality is determined when lower bids are lower than the average of the bids submitted plus a differential, and secondly the group B with $19 \%$, where the assumptions of disproportionality are those referred to in Article 85 of the Regulation of the Law for Public Administration Contracts.

Having identified the main criteria of disproportionality (with different variations) it is necessary to study their behaviour by applying data from the economic opening of two projects; one, a project from the Buildings subsector with few bidders, and the other from the Civil Engineering subsector with many bidders. The project from the Buildings subsector is the construction of the SUNP VI Sports Centre by the Council of Sagunto, file 59/90, with a budget of EUR 2,786,034.48 tender + VAT. Whereas the project from the Civil Engineering subsector is for the repaving of the streets within the Huerta Nueva area and The Sax Avenue in Elda (Alicante); tendered by the Department of Infrastructure and Transport of the Generalitat Valenciana, file: 2010/09/0103, with a budget of EUR 1,366,444.98 tender + VAT.

Table 4. Economic Opening Results for SUNP VI Sports Centre by the Council of Sagunto.

\begin{tabular}{llll}
\hline Tendering Company & & Offer (Euros) & Base Rate (\%) \\
\hline Via Latina S.A. & I & $2,667,273.43 €$ & 4.26 \\
Elecnor & II & $2,758,174.14 €$ & 1.00 \\
Secopsa & III & $2,769,742.11 €$ & 0.58 \\
Construcciones S.A. & IV & $2,307,981.50 €$ & 17.16 \\
Valcomar S.A. & V & $2,368,129.31 €$ & 15.00 \\
Intersa Levante S.A. &
\end{tabular}

\section{DISPROPORTIONALITY CRITERIA}
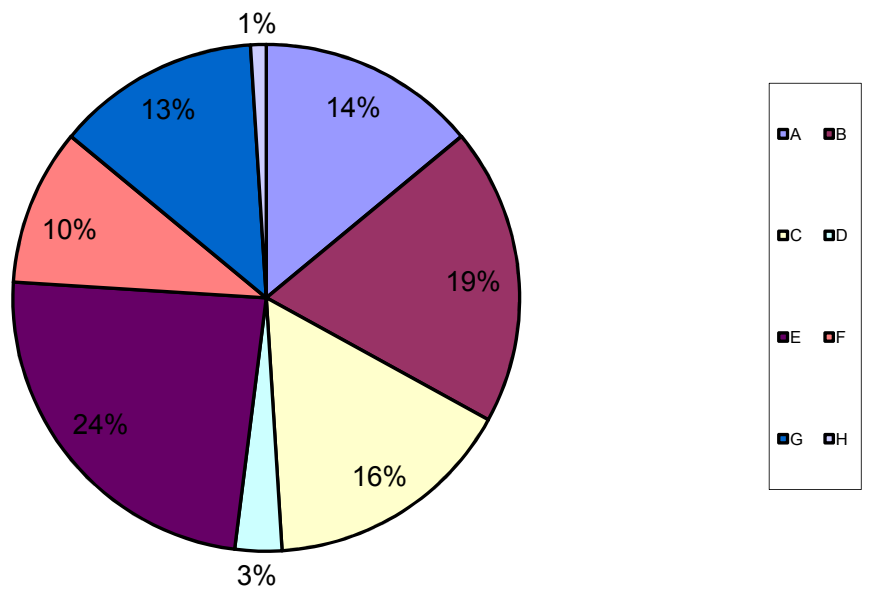

Figure 1. Disproportionality criteria for certain groups. 
Table 5. Economic Opening Results for the repaving of the streets within the Huerta Nueva area and the Sax Avenue in Elda (Alicante).

\begin{tabular}{|c|c|c|c|}
\hline Tendering Company & & Offer (Euros) & Base Rate (\%) \\
\hline Electricidad Paquete-Mainco & I & $1,355,932.21$ & 0.77 \\
\hline Gestaser-Secopsa & II & $1,332,016.26$ & 2.52 \\
\hline Rover Alcisa & III & $1,328,000.00$ & 2.81 \\
\hline $\begin{array}{l}\text { Mac-Puar } \\
\text { Servicios Industriales }\end{array}$ & IV & $1,325,451.63$ & 3.00 \\
\hline Asfaltos Guerola-Symetra & $\mathrm{V}$ & $1,318,619.41$ & 3.50 \\
\hline $\begin{array}{l}\text { Assignia, S.A.-Ing. } \\
\text { Del Agua Y La Energia }\end{array}$ & VI & $1,309,054.29$ & 4.20 \\
\hline Vaseco-Villegas & VII & $1,298,669.31$ & 4.96 \\
\hline Saico & VIII & $1,298,122.72$ & 5.00 \\
\hline Beneaguas-Electrisur & IX & $1,288,782.94$ & 5.68 \\
\hline $\begin{array}{l}\text { Construcciones } \\
\text { Proyme Alginet }\end{array}$ & $\mathrm{X}$ & $1,284,458.28$ & 6.00 \\
\hline Edificaciones Castelló-Urbamed & $\mathrm{XI}$ & $1,283,775.06$ & 6.05 \\
\hline $\begin{array}{l}\text { S.A. De Riegos } \\
\text { Camios Y Obras }\end{array}$ & XII & $1,277,659.35$ & 6.50 \\
\hline Renos & XIII & $1,258,085.89$ & 7.93 \\
\hline Ezentis Infraestructuras & XIV & $1,256,856.09$ & 8.02 \\
\hline Pavasal & $\mathrm{XV}$ & $1,250,559.46$ & 8.48 \\
\hline Grupo Generala-Reticulares & XVI & $1,249,067.36$ & 8.59 \\
\hline Construcciones Frances & XVII & $1,249,019.00$ & 8.59 \\
\hline Cyes Infraestructuras & XVIII & $1,246,197.82$ & 8.80 \\
\hline $\begin{array}{l}\text { Bm3 Obras Y } \\
\text { Servi-Riegos Vinalopó }\end{array}$ & XIX & $1,241,688.55$ & 9.13 \\
\hline Torrescamara & $\mathrm{XX}$ & $1,232,533.37$ & 9.80 \\
\hline Coinger & XXI & $1,229,800.48$ & 10.00 \\
\hline Grupo Bertolín-Procumasa & XXII & $1,225,154.57$ & 10.34 \\
\hline Ecisa & XXIII & $1,225,000.00$ & 10.35 \\
\hline Ocide & XXIV & $1,222,421.68$ & 10.54 \\
\hline Binaria & $\mathrm{XXV}$ & $1,213,403.14$ & 11.20 \\
\hline Becsa & XXVI & $1,207,720.72$ & 11.62 \\
\hline Jotsa-Geosa & XXVII & $1,206,530.97$ & 11.70 \\
\hline $\begin{array}{l}\text { Serrano Aznar } \\
\text { Obras Publicas }\end{array}$ & XXVIII & $1,201,378.00$ & 12.08 \\
\hline $\begin{array}{l}\text { Dopema-Esclapes } \\
\text { E Hijos }\end{array}$ & XXIX & $1,189,490.36$ & 12.95 \\
\hline Enrique Ortiz E Hijos & $\mathrm{XXX}$ & $1,183,103.45$ & 13.42 \\
\hline Arcion & XXXI & $1,172,683.08$ & 14.18 \\
\hline Adesval-Electotecnica Morales & XXXII & $1,168,310.46$ & 14.50 \\
\hline $\begin{array}{l}\text { Chm Obras } \\
\text { E Infraestructuras }\end{array}$ & XXXIII & $1,159,291.92$ & 15.16 \\
\hline Intersa Levante & XXXIV & $1,116,802.00$ & 18.27 \\
\hline
\end{tabular}

\section{Results}

The application of the various criteria of disproportionality against the economic opening results for the projects produce the following results, expressing the limits of risk in terms of base rates and the bid price.

The graphs and the table 6 show that the criteria based on a percentage of the maximum base rate permitted according to the bid price ( $\mathrm{G} 1$ to $\mathrm{G} 5$ criteria) highlight that bidders adjust their offer to the percentage of the maximum base rate which normally coincides with the maximum score of the economic criteria. Therefore, all tendering companies or almost all, achieve the highest score in that section. The choice of the contracting company is mainly based on the evaluation criteria and with great the subjectivity that this process can incur.

This process with thirty-four bidders presents a base rate of 8.72 and a standard deviation of 4.05 , which at least 
exhibits greater homogeneity with respect to the five-bidder sample. Unless there are large differential criteria, this generates a disproportionality limit by applying criteria based on a reference price using standard deviation (Group
A), that which is based on Article 85 of the Regulations of the LPAC (Group B and D) or even the criteria based on a deviation of the mean of the bidders ( $\mathrm{E}$ and $\mathrm{F}$ ) which all present very similar values.

Table 6. Limits of disproportionality in terms of base rates and price.

\begin{tabular}{|c|c|c|c|c|c|}
\hline \multirow[b]{2}{*}{ Criteria } & \multicolumn{2}{|c|}{ Opening Risk Limit For Building Projects } & \multicolumn{2}{|c|}{ Opening Risk Limit For Civil Engineering Projects } & \multirow{2}{*}{$\begin{array}{l}\text { Opening } \\
\text { Difference } \\
\%\end{array}$} \\
\hline & $\%$ & Euros & $\%$ & Euros & \\
\hline A1 & 6.45 & $179,699.22$ & 11.7 & $159,874.06$ & 5.25 \\
\hline A2 & 2.34 & $65,193.21$ & 10.44 & $142,631.17$ & 8.10 \\
\hline A3 & 6.85 & $190,891.08$ & 13.26 & $181,238.59$ & 6.41 \\
\hline A4 & 5.95 & $165,769.05$ & 12.7 & $173,538.51$ & 6.75 \\
\hline A5 & 7.83 & $218,208.38$ & 14.18 & $193,714.45$ & 6,35 \\
\hline B & 16.84 & $460,629.47$ & 17.85 & $243,942.75$ & 1.01 \\
\hline D1 & 16.53 & $460,629.47$ & 14.30 & $195,467.76$ & 2.23 \\
\hline D2 & 14.07 & $391,972.59$ & 15.34 & $209,589.58$ & 1.27 \\
\hline E1 & 12.60 & $351,040.34$ & 13.72 & $187,542.53$ & 1.12 \\
\hline E2 & 17.60 & $490,342.07$ & 18.72 & $255,864.78$ & 1.12 \\
\hline E3 & 14.60 & $406,761.03$ & 15.72 & $214,871.43$ & 1.12 \\
\hline E4 & 5.07 & $141,251.95$ & 31.51 & $430,517.50$ & 26.44 \\
\hline E5 & 8.36 & $232,912.48$ & 9.60 & $131,142.31$ & 1.24 \\
\hline E6 & 21.46 & $597,913.40$ & 22.42 & $306,303.98$ & 0.96 \\
\hline E7 & 27.60 & $768,945.52$ & 28.72 & $392,509.28$ & 1.12 \\
\hline E8 & 14.67 & $408,711.26$ & 13.72 & $187,476.25$ & 0.95 \\
\hline $\mathrm{F} 1$ & 12.22 & $340,487.39$ & 13.29 & $181,581.51$ & 1.07 \\
\hline $\mathrm{F} 2$ & 16.84 & $469,200.39$ & 17.85 & $243,942.75$ & 1.01 \\
\hline F3 & 26.08 & $726,626.40$ & 26.98 & $368,665.22$ & 0.90 \\
\hline F4 & 14.67 & $408,793.81$ & 12.77 & $174,525.06$ & 1.90 \\
\hline G1 & 10.00 & $278,603.45$ & 10.00 & $136,644.50$ & - \\
\hline $\mathrm{G} 2$ & 12.00 & $334,324.14$ & 12.00 & $163,973.40$ & - \\
\hline G3 & 15.00 & $417,905.17$ & 15.00 & $204,966.75$ & - \\
\hline G4 & 20.00 & $557,206.90$ & 20.00 & $273,289.00$ & - \\
\hline G5 & 25.00 & $696,508.62$ & 25.00 & $341,611.25$ & - \\
\hline $\mathrm{H}$ & 28.56 & $795,691.45$ & 28.56 & $390,256.69$ & - \\
\hline
\end{tabular}

The results can be represented in the graph that follows:

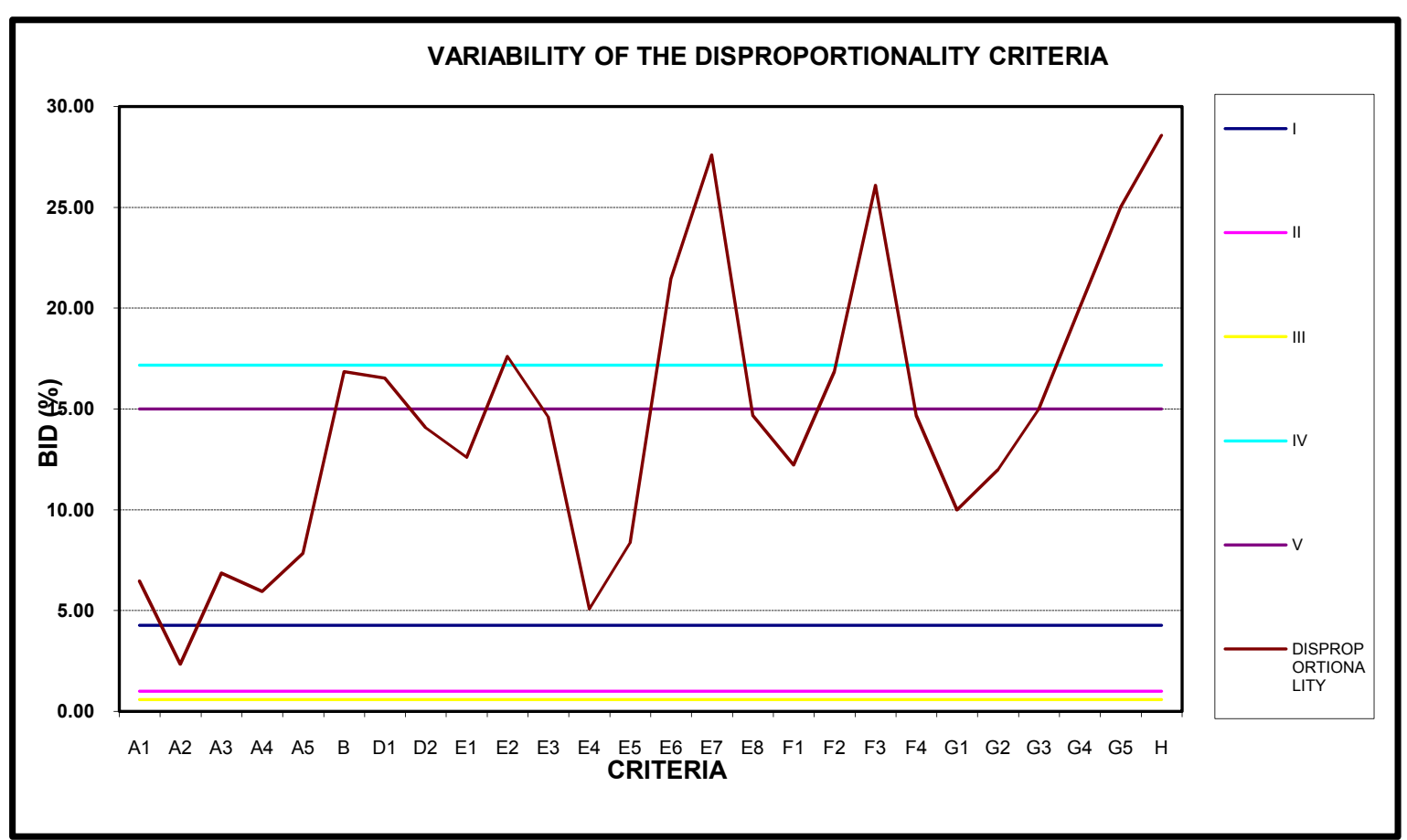

Figure 2. Variability of the disproportionality criteria on economic opening results for SUNP VI Sports Centre by the Council of Sagunto. 


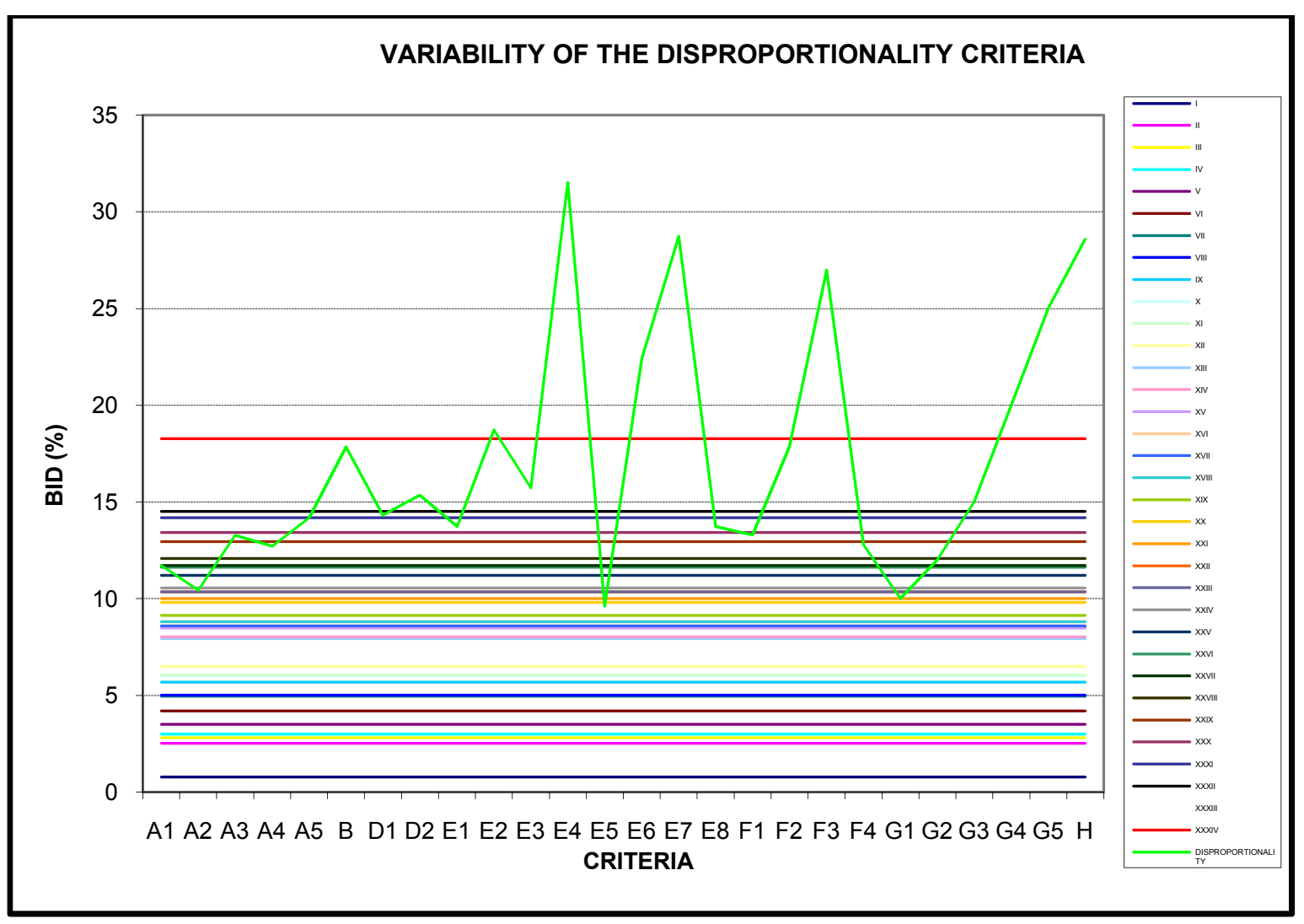

Figure 3. Variability of the disproportionality criteria on economic opening results for the repaving of the streets within the Barrio Huerta Nueva area and The Sax Avenue in Elda (Alicante).

In the case of the sample of five bidders, the offers present a base rate of 7.60 and a standard deviation of 7.07 , with offers at opposite ends of the spectrum. In this case, the use of scoring criteria based on the calculation of a base rate or price (group A), values much smaller than in the other groups of scoring criteria (groups B, D and F) are reached.

Special importance must be given to the application mathematical analysis to achieve the results of the two economic openings, criteria E4, E5 and H. There is a surprise with regard to the criterion $\mathrm{E} 4$ where the risk limit is set by multiplying a coefficient of 0.75 by the average value of the tender offers, both the highest and lowest tenders are eliminated from the calculation of the mean base rate therefore generating a very low base rate value for the Buildings project whereas for the results for the Civil Engineering project we see the lowest base rate; a true reflection of the number of bidders, their offers and the disparity between them.

On the other hand the criterion E5, that sets the limit of disproportionality by multiplying by a factor of value 1.1 (10\% reflects the differential), presents a disparity between the two series. We see a lower numerical criterion which deviates from the E5 homogeneous behaviour of the other criteria of the group (the risk was determined from the mean base rate plus a percentage). The criterion $\mathrm{H}$ sets the limit of risk at 10 percentage points against a base rate value therefore obtaining a fixed value, in this case $28.56 \%$, which none of the bidders managed to reach.

\section{Conclusions}

The first point to be noted as a result of the analysis of the criteria of disproportionality is the number and disparity of the formulae; the Administration must regulate common rules or processes for all procedures, or at least establish guidelines depending on the type of work and/or the number of bidders.

The next question would be: is the administration really interested in the regulation of issues of abnormality or disproportionality? Contracting authorities are faced with the following dichotomy: regulate more or be more demanding on the criterion of disproportionality and obtain less substantial bids in exchange for avoiding project modifications and/or contradictory quotes throughout the project. In addition to this, allowing much more attractive and lower prices even at the risk of jeopardizing the contractor or the viability of the project. In these examples allowing the application of a risk criterion such as A2 with a base rate limit of $2.34 \%$ in the case of the Buildings project against the criterion $\mathrm{H}$ with a value of $28.56 \%$ would mean an economic decrease by awarding the project for a price of $450,192.64$ euros, an altogether negligible $16.16 \%$.

Regarding the formulae to be used, it seems clear that it should be possible to use formulae that base the limit of disproportionality on a percentage of the bid price. This is because, in practice, it appears that the administration is 
setting the price at which it wants the project to be carried out at, thereby removing the importance of price from the tender acceptance decision.

It seems complicated to be able to choose the optimum formula, but at least we are able to indicate that the formulae based on the disproportionality limit selection which is in turn centred on a base rate plus a differential presented more homogeneous behaviour with both high and low numbers of bidders. Here we can at least try, mathematically, to establish a point of reference which acts as a centre of gravity for all bids submitted.

\section{References}

[1] European Union. Directiva 2004/18/CE del Parlamento Europeo y del Consejo, de 31 de Marzo de 2004, sobre coordinación de los procedimientos de adjudicación de los contratos públicos de obras, de suministro y de servicios. Diario Oficial de la Unión Europea, 30 de Abril de 2004, L 134 p.114-240.

[2] Spain. Ley 30/2007, de 30 de Octubre, de Contratos del Sector Público. Boletín Oficial del Estado, 31 de Octubre de 2007, núm. 261 p. 44336-44436.

[3] Spain. Real Decreto Legislativo 3/2011, de 14 de Noviembre, por el que se aprueba el texto refundido de la Ley de Contratos del Sector Público. Boletín Oficial del Estado, 16 de Noviembre de 2011, núm. 276, p.117729-117914.

[4] De Hoyos-Maroto, B. "Criterios de selección y criterios de adjudicación en la contratación administrativa: problemas de delimitación". Cuenta con el IGAE, Vol. 11, p.30-36, 2005.

[5] Fueyo-Bros, M. "Criterios objetivos de valoración versus objetivos de los criterios de adjudicación". El Consultor de los Ayuntamientos y de los Juzgados, 15-16, p. 2196-2280, 2009.

[6] Martín-Seco, J.F. "El Precio como criterio de adjudicación en los concursos". Cuenta con el IGAE. Vol. 7 p.11-26, 2003.

[7] Padrós-Reig, C. "La regulación de la baja temeraria en los procedimientos de contratación. Fundamentación actual e historia normativa". Revista de Administración Pública. Vol. 181 p. $267-300,2010$.

[8] Spain. Ley 53/1999, de 28 de Diciembre, por la que se modifica la Ley 13/1995, de 18 de Mayo, de Contratos de las Administraciones Públicas. Boletín Oficial del Estado, núm. 311, p.45788-45816.

[9] Tan, Y.T., Shen, L.Y., Khalid, A.G. "An examination of the factors affecting contractor's competition strategy: a Hong Kong study". International Journal of Project Organisation and Management. Vol. 1, p. 4-23, 2008. DOI: 10.1504/IJPOM.2008.020026.

[10] Crowley, L.G., Hancher, D.E. "Risk assessment of competitive procurement". Journal of Construction Engineering and Management. 121(2), p. 230-237, 1995. DOI: 10.1061/(ASCE)0733-9364(1995)121:2(230).

[11] Lo, W., Lin, C.L., Yan, M.R. "Contractor's opportunistic bidding behaviour and equilibrum price level in the construction market". Journal of Construction Engineering and Management. 133(6), p. 409-416, 2007. DOI:
10.1061/(ASCE)0733-9364(2007)133:6(409).

[12] Zack, J. "Claimsmanship: current perspective". Journal of Construction Engineering and Management. 119(3), p. 480-497, 1993. DOI: 10.1061/(ASCE) 0733-9364 (1993) 119:3(480)

[13] Ruiz-Ojeda, A. (Dir) et al. Derecho de la contratación pública y regulada. Madrid: Editorial Civitas, 2004, p-436. ISBN: 8447021424

[14] Mohamed-Khaled, A., Khoury-Shafik, S., Hafez-Sherif, M. "Contractor's decision for bid profit reduction within opportunistic bidding behaviour of claims recovery". International Journal of Project Management. 29, p. 93-107, 2011. DOI: 10.106/j.ijproman.2009.12.003.

[15] Bendaña-Jácome, R., Del Caño-Gochi, A., De la Cruz-López, P. and Castro-Rascado, A. "Selección multicriterio de contratistas de obras. Enfoque basado en redes neuronales". Dyna Ingeniería e Industria. Vol. 85(1), p. 71-84, 2010.

[16] Ballesteros-Pérez, P., González-Cruz, M.C. and Cañabate-Grimal, A. "Mathematical relationships between scoring parameters in capped tendering". International Journal of Project Management. Vol 30, p. 850-862, 2012. DOI: 10.1016/j.ijproman.2012.01.008.

[17] Ballesteros-Pérez, P., González-Cruz, M.C., Pastor-Ferrando, J.P. and Fernández-Diego, M. "The iso-Score Curve Graph. A new tool for competitive bidding". Automation in Construction. Vol 22, p. 481-490, 2012. DOI: 10.1016/j.autcon.2011.11.007

[18] Pastor-Ferrando, J.P., Aragonés-Beltrán, P., Hospitaler-Pérez, A. and García-Melón, M. "An ANP and AHP based approach for weighting criteria in public works bidding". Journal of the Operational Research Society. 61, p. 905-916, 2010. DOI: 10.1057/jors.2010.13.

[19] Tone, K. "A slacks-based measure of super-efficency in data envelopment analysis". European Journal of Operational Research. Vol 143 (1) p. 32-41, 2002. DOI: 10.1016/S0377-2217(01)00324-1.

[20] Falagario, M., Sciancalepore, F., Costantino, N. and Pietroforte, R. "Using a DEA-cross efficiency approach in public procurement tenders" European Journal of Operational Research. 218(2), 2012, p. 523-530. DOI: 10.1016/j.ejor.2011.10.031

[21] Spain. Decreto 3410/1975, de 25 de Noviembre, por el que se aprueba el Reglamento de Contratación del Estado". Boletín Oficial del Estado, 27 de Diciembre de 1975, núm. 311, p.26776-26887.

[22] Spain. Real Decreto 1098/2001, de 12 de Octubre, por el que se aprueba el Reglamento general de la Ley de Contratos de las Administraciones Públicas. Boletín Oficial del Estado, 26 de Octubre de 2011, núm. 257, p.39252-39371.

[23] ABSAC. Report 18/96, de 5 de Junio de 1996. "Consideración de las ofertas anormalmente bajas en el concurso y posibilidad de aplicación de las mismas del criterio determinado en el artículo 109 del Reglamento General de Contratación".

[24] ABSAC. Report 27/98, de 11 de Noviembre de 1998. "Ponderación del criterio del precio en concursos".

[25] ABSAC. Report 28/05, de 29 de Junio de 2005, "Posibilidad 
de aplicar los preceptos relativos a bajas temerarias a la adjudicación de un contrato mediante la forma de concurso cuyo objeto es la enajenación de parcelas municipales. Incompetencia de la Junta Consultiva de Contratación Administrativa para la apreciación de los criterios de adjudicación".

[26] ABSAC. Report 58/08, de 31 de Marzo de 2009, "Requisitos para la aplicación de la oferta anormalmente baja cuando el contrato se adjudica mediante la aplicación de más de un criterio de adjudicación. Constancia en el pliego de cláusulas administrativas particulares de los criterios aplicables".

[27] Ballesteros-Moffa L.A. "La selección del contratista en el Sector Público: Criterios reglados y discrecionales en la valoración de las ofertas". Revista de Administración Pública. Vol. 180, p. 21-57, 2009.

[28] Waara F., Bröchner J. "Price and Nonprice Criteria for Contractor Selection". Journal of Construction Engineering and Management. 132(8), p. 797-804, 2006. DOI: 10.1061/(ASCE)0733-9364(2006)132:8(797). 